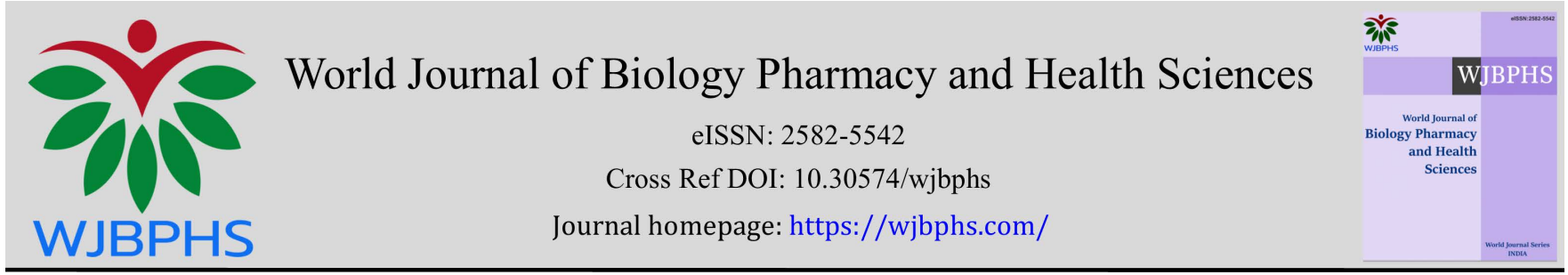

(CASE REPORT)

\title{
A case report on Rheumatoid Arthritis with sickle cell trait
}

\author{
Priyancy Patel ${ }^{1}$, Twinkle Rathod ${ }^{1}$, Mohit Buddhadev ${ }^{2,}{ }^{*}$, S P Srinivas Nayak ${ }^{2}$ and Gunosindhu Chakraborthy ${ }^{1}$ \\ ${ }^{1}$ Parul Institute of Pharmacy and Research, Parul University, Vadodara, Gujarat, India. \\ 2 Department of Pharmacy Practice, Parul Institute of Pharmacy and Research, Parul University, Vadodara, Gujarat, India.
}

World Journal of Biology Pharmacy and Health Sciences, 2021, 07(03), 015-018

Publication history: Received on 01 August 2021; revised on 03 September 2021; accepted on 05 September 2021

Article DOI: https://doi.org/10.30574/wjbphs.2021.7.3.0089

\begin{abstract}
A female patient aged 6 years, a suspected case of sickle cell trait (SCT) having symptoms of Rheumatoid arthritis (RA), while evaluating joint complaints in adult sickle cell disease (SCD) patients, a number of sickle cell-based entities come to mind such as avascular necrosis, osteomyelitis, bone infarcts, and septic arthritis. RA is a chronic systemic inflammatory disease, many reports highlighted the occurrence of RA in SCD presenting as diagnostic challenges for cases with chronic inflammatory arthritis, SCT also have appeared to persist in some populations at a perplexingly high rate given the degree of early mortality of homozygosity of SCD, our case report showed that not only SCD but if a patient has SCT they can develop RA as complication. Our case report concludes that during the evaluation of a SCT patient who presents with chronic synovitis, one should strongly consider the possibility of coexistence of RA and SCT.
\end{abstract}

Keywords: Sickle cell trait; Rheumatoid arthritis; Sickle cell disease; Genetic predisposition

\section{Introduction}

Rheumatoid arthritis (RA) is a chronic systemic inflammatory disease characterized by inflammation and synovitis leading to damage of cartilage and juxta-articular bone destruction [1]. Environmental factors (smoking and infection), as well as genetic predisposition, are known to play a role in the development of RA. Among Caucasian patients, the human leukocyte antigen-DRB1 (HLA-DRB1) alleles containing the shared epitope, are markers of disease risk and severity. However, HLADRB1 has been found in only one third of African-Americans (AA) RA patients,[1] along with RA, While evaluating joint complaints in adult sickle cell disease (SCD) patients, a number of sickle cell-based entities come to mind such as avascular necrosis, osteomyelitis, bone infarcts, and septic arthritis[2] this diagnosis is generally overlooked and rarely considered. Anecdotal reports highlighted the occurrence of RA in SCD presenting as diagnostic challenges for cases with chronic inflammatory arthritis, joint effusions, erosive arthritis and non-gouty arthritis [3-5] The molecular underpinnings of SCD fascinated scientists of the time, as it had been noted that the heterozygote state, sickle cell trait (SCT), appeared to persist in some populations at a perplexingly high rate given the degree of early mortality of homozygosity of SCD. Prevalences as high as $20 \%-40 \%$ had been described in certain African tribes, Mediterranean populations, and Indian aboriginal groups, and the overlap of the SCT allele frequency patterns and malarial endemicity soon led A.C. Allison to the theory that sickle hemoglobin ( $\mathrm{HbS})$ must confer a selective advantage of malarial resistance in the carrier state.[4] In SCD, the red blood cells (RBC) dehydrate causing increased viscosity of the cytosol; RBC become unable to maintain their flexibility and shape and acquire the typical sickle shape [6]. RBC membrane in SCD have a tendency to adhere to the endothelium [7]. Vaso-occlusive crises (VOC) results in blockage of the blood flow by the sickled red cells which lead to acute chest syndrome, ischemia, stroke, infarcts, pain, bone marrow degeneration and bony infarcts. The Centers for Disease Control and Prevention estimate that about 100,000 Americans are affected by SCD with a life expectancy of 43 and 41 years of age, for women and men respectively [8,9].In a study revealed that the prevalence of SCD coexisting with RA was $0.94 \%$, which is similar to the prevalence of RA among the

\footnotetext{
${ }^{*}$ Corresponding author: Mohit Buddhadev

Department. of Pharmacy Practice, PIPR, Parul University, Vadodara, Gujarat, India.
} 
general population. Their patients, mostly from Afro-Caribbean descent, with SCD-RA were compared to age and sex matched patients with SCD and RA [10]. The SCD-RA patients had significantly lower hemoglobin and tended to have a lower BMI, increased periarticular osteopenia, erosive arthritis, prolonged morning stiffness, increased number of hospitalizations and longer hospital stay [11] For a definitive classification of RA, the following are required: confirmed synovitis in at least one joint, absence of an alternative diagnosis, and a total score of at least six of a possible 10 in the following four domains: involved joints(range 0-5), rheumatoid factor (RF) or anti-cyclic citrullinated peptide antibody (anti-CCP) (range 0-3), elevated erythrocyte sedimentation rate (ESR) or C-reactive protein(CRP) (range $0-1$ ), and symptom duration of six weeks or more (range 0-1)[12] It is strongly advised to keep in mind the possibility of RA coexistence when the clinical course of the painful crisis in SCD patients does not follow the expected trajectory. The prompt use of agents which target the underlying pathophysiology of RA remains the best option for the prevention of potential damage in these patients, who usually present with comorbidities due to SCD.

\section{Case report}

A 6-year-old female child presented with complaints of swelling over right thigh since 1 year (accidentally noticed, static in size, knee swelling), swelling over right ankle (pain), cough and cold since 1 day, Low grade intermittent fever $\left(100.2^{\circ} \mathrm{F}\right)$ since 1 day that relieved by medication, problem and pain while walking due to swelling of knee.

\section{Physical examination}

Upon physical examination swelling over right thigh and knee was noted along with pain. On General examination the patient was fair, cooperative and coherent, Head, Eyes, Ears, Nose, Throat, Mouth, Neck (HEENTMN) were found Normal, CNS: Conscious and oriented, no neurological deficits, CVS: S1, S2 (positive), EF 60\%, no murmurs noted, RS: BLAE (+). No signs of wheezing or crackles, GIT: soft, non-distended.

\subsection{Vitals}

Blood Pressure (BP): 106/60 mm of Hg, Respiratory Rate (RR): 23 breaths/minute, Pulse rate (PR): 112 beats/minute, Temperature: $100.2^{\circ} \mathrm{F}$, Oxygen saturation (Sp02): $98 \%$.

\subsection{Patient demographics}

Allergies: No allergies were noted. Medical history: Diagnosed with sickle cell trait 6 months ago. Patient had swelling over right knee without pain since 1 year which was noticed recently when the child developed pain while walking. Medication history: Patient was not on any medication. Social history: Non-smoker and non-alcoholic. Family history: Patient's mother has Sickle cell disease, also had 6 times PCV transfusion and is on Hydroxyurea tablet. Developmental history: Normal, school going child.

\subsection{Laboratory findings}

Table 1 laboratory findings

\begin{tabular}{|l|l|l|l|}
\hline \multicolumn{1}{|c|}{ Parameters } & \multicolumn{1}{c|}{ Obtained value } & \multicolumn{1}{c|}{ Normal range } & \multicolumn{1}{c|}{ Interference } \\
\hline Hemoglobin & $11.50 \mathrm{~g} / \mathrm{dl}$ & $11.1-14.1 \mathrm{~g} / \mathrm{dl}$ & Normal \\
\hline RBCs & $4.44 \mathrm{mill} / \mathrm{cumm}$ & $3.9-5.1 \mathrm{mill} / \mathrm{cumm}$ & Normal \\
\hline WBCs & 14500 cells/cumm & $5000-13000$ cells/cumm & Infection/Inflammation \\
\hline Neutrophils & $54 \%$ & $30-50 \%$ & Neutrophilia \\
\hline Lymphocytes & $44 \%$ & $50-80 \%$ & Lymphocytopenia \\
\hline Monocytes & $1 \%$ & $2-12 \%$ & Monocytopenia \\
\hline Eosinophils & $1 \%$ & $1-6 \%$ & Normal \\
\hline MCH & $24.90 \mathrm{pg}$ & $24-30 \mathrm{pg}$ & Normal \\
\hline MCHC & $35.90 \mathrm{~g} / \mathrm{dl}$ & $29-37 \mathrm{~g} / \mathrm{dl}$ & Normal \\
\hline MCV & $69 \mathrm{fL}$ & $75-87 \mathrm{fL}$ & Microcytic Anemia \\
\hline PCV & $32 \%$ & $34-40 \%$ & Anemia \\
\hline
\end{tabular}




\begin{tabular}{|l|l|l|l|}
\hline RDWs & $14.10 \%$ & $11.6-14 \%$ & Macrocytic Anemia \\
\hline SGOT (AST) & $31 \mathrm{IU} / \mathrm{L}$ & $0-37 \mathrm{IU} / \mathrm{L}$ & Normal \\
\hline SGPT (ALT) & $11 \mathrm{IU} / \mathrm{L}$ & $0-46 \mathrm{IU} / \mathrm{L}$ & Normal \\
\hline Serum ALP & $336 \mathrm{IU} / \mathrm{L}$ & $28-382 \mathrm{IU} / \mathrm{L}$ & Normal \\
\hline Total Bilirubin & $0.80 \mathrm{mg} / \mathrm{dl}$ & $0.1-1.2 \mathrm{mg} / \mathrm{dl}$ & Normal \\
\hline Direct Bilirubin & $0.20 \mathrm{mg} / \mathrm{dl}$ & $0-0.4 \mathrm{mg} / \mathrm{dl}$ & Normal \\
\hline Indirect Bilirubin & $0.60 \mathrm{mg} / \mathrm{dl}$ & $0.1-0.8 \mathrm{mg} / \mathrm{dl}$ & Normal \\
\hline Total Protein & $7 \mathrm{~g} / \mathrm{dl}$ & $6-8 \mathrm{~g} / \mathrm{dl}$ & Normal \\
\hline Albumin & $4.10 \mathrm{~g} / \mathrm{dl}$ & $3.2-5 \mathrm{~g} / \mathrm{dl}$ & Normal \\
\hline Sodium & $137 \mathrm{mEq} / \mathrm{L}$ & $135-145 \mathrm{mEq} / \mathrm{L}$ & Normal \\
\hline Potassium & $4.30 \mathrm{mEq} / \mathrm{L}$ & $3.5-5 \mathrm{mEq} / \mathrm{L}$ & Normal \\
\hline Calcium & $1.28 \mathrm{mg} / \mathrm{dl}$ & $1.12-1.32 \mathrm{mg} / \mathrm{dl}$ & Normal \\
\hline Urea & $19 \mathrm{mg} / \mathrm{dl}$ & $14-40 \mathrm{mg} / \mathrm{dl}$ & Normal \\
\hline Creatinine & $0.78 \mathrm{mg} / \mathrm{dl}$ & $0.6-1.2 \mathrm{mg} / \mathrm{dl}$ & Normal \\
\hline Lactate Dehydrogenase & $452 \mathrm{U} / \mathrm{L}$ & $230-460 \mathrm{U} / \mathrm{L}$ & Normal \\
\hline
\end{tabular}

\subsection{Diagnostic tests}

USG of local part (Right knee) - Moderate supra patellar effusion with $2.4 \mathrm{~mm}$ with minimal to mild synovial thickening in right knee, Malarial parasite - Not detected, Anti-nuclear antibody (ANA): 58 Units: Positive, RA factor (ELISA): Positive, Anti Citrullinated protein antibody blood test: Positive.

Final diagnosis: rheumatoid arthritis with sickle cell trait

\subsection{Plan of action}

Table 2 Supportive Management Chart

\begin{tabular}{|c|l|c|c|c|}
\hline Sr. & Drug & Dose & Route & Frequency \\
\hline 1. & Inj. Amoxicillin Clavulanate & $450 \mathrm{mg}$ & IV & TID \\
\hline 2. & Inj. Paracetamol & $15 \mathrm{mg}$ & IV & SOS \\
\hline 3. & Inj. Pantoprazole & $15 \mathrm{mg}$ & IV & OD \\
\hline 4. & Tab. Naproxen & $250 \mathrm{mg}$ & PO & BD \\
\hline 5. & Tab. Prednisolone & $5 \mathrm{mg}$ & PO & TID $(1 / 2-1-1 / 2)$ \\
\hline 6. & Tab. Multivitamin B complex & --- & PO & BD \\
\hline 7. & Tab. Folic acid & $5 \mathrm{mg}$ & PO & OD \\
\hline 8. & Tab. Calcium + Vitamin D3 & --- & PO & BD \\
\hline
\end{tabular}

\section{Discussion}

The patient being described is a 6-year-old girl with SCT, not on regular medications. Past history showed that her Sickling test was performed and positive results were obtained. Further HPLC test was done to rule out Sickle cell trait. She never faced any flares of RA previously. Also, RA was diagnosed when she presented with complaints of pain in right knee and difficulty in walking. This case, therefore, highlights the importance of ruling out arthritis in all cases of SCT or SCD, if patient presents with acute onset of pain, swelling over right ankle etc. The patient was managed very well with the medications mentioned (Table.2), patient was stabilized and Discharged. 


\section{Conclusion}

In conclusion, our case report showed that not only SCD but if a patient has SCT they can develop RA as complication which is not yet observed. Hence, during the evaluation of a SCT patient who presents with chronic synovitis, strongly consider the possibility of coexistence of RA and SCT; keeping in mind that the absence of musculoskeletal symptoms in SCT can masquerade and delay the diagnosis of RA in this patient population. Though not fatal but early diagnosis and treatment can reduce the prevalence of complications and overall health of patients. It is possible that the underlying inflammatory mechanisms present in SCT and RA may worsen the clinical manifestations of each disease if not managed properly.

\section{Compliance with ethical standards}

\section{Acknowledgments}

We would like to thank Principal Dr. Gunosindhu Chakraborthy, Principal and Professor PIPR, Parul University, all the Authors and PIPR Staff.

\section{Disclosure of conflict of interest}

All authors declare that they have no conflict of interest.

\section{Statement of informed consent}

Informed consent was obtained from the individual participant included in the study. No Animal is used in the study and direct intervention was not performed.

\section{References}

[1] McInnes IB, Schett G. The pathogenesis of rheumatoid arthritis. N Engl J Med. 2011; 365(23): 2205-2019.

[2] Bridges SL, Hughes LB, Mikuls TR, Howard G, Tiwari HK, et al. Early rheumatoid arthritis in African-Americans: The CLEAR Registry. Clinical and experimental rheumatology. 2003; 21(5 Suppl 31): S138-145.

[3] Coodley ELK, Sickle MJ. Cell disease simulating advanced rheumatoid arthritis: Report of a case. Calif Med. 1949; 70(6): 459-463.

[4] Allison AC. The distribution of the sickle-cell trait in East Africa and elsewhere, and its apparent relationship to the incidence of subtertian malaria. Trans R Soc Trop Med Hyg. 1954; 48(4): 312-318.

[5] Schumacher HR, Dorwart BB, Bond J, Alavi A, Miller W. Chronic synovitis with early cartilage destruction in sickle cell disease. Annals of the rheumatic diseases. 1977; 36(5): 413-419.

[6] Rees DC, Williams TN, Gladwin MT. Sickle-cell disease. Lancet. 2010; 376(9757): 2018-2031.

[7] Manwani D, Frenette PS. Vaso-occlusion in sickle cell disease: pathophysiology and novel targeted therapies. Blood. 2013; 122(24): 3892-3898.

[8] Zennadi R, Chien A, Xu K, Batchvarova M, Telen MJ. Sickle red cells induce adhesion of lymphocytes and monocytes to endothelium. Blood. 2008; 112(8): 3474-3483.

[9] Paulukonis ST, Eckma JR, Snyder AB, Hagar W, Feuchtbaum LB, et al. Defining Sickle Cell Disease Mortality Using a Population-Based Surveillance System. Public health reports. 2016; 131(2): 367-375.

[10] Isabel MM. When Two Diseases Cross their Paths: The Diagnostic Challenge of Rheumatoid Arthritis in Sickle Cell Disease 2/5 Patients. Res Arthritis Bone Study. 2018; 1(1): RABS.000503.

[11] McFarlane IM OD, Pathiparampil J, Sanchez R, Levinson J, Barrett Campbell O, et al. Prevalence and Clinical Characteristics of Rheumatoid Arthritis in an Inner City Population with Sickle Cell Disease. Rheumatology (Sunnyvale). 2017; 7: 218.

[12] Aletaha D, Neogi T, Silman AJ, Funovits J, Felson DT, Bingham CO $3^{\text {rd }}$,et al. Rheumatoid arthritis classification criteria: An American Col-lege of Rheumatology/European League Against Rheumatism collaborative initiative. Arthritis Rheum. 2010; 62(9): 2569-81. 